EMERGING VOICES

\title{
Volunteers as Agents of Change: A Study of the Manipulation of Scientific Knowledge through Translating Hedges in Popular Science Texts into Arabic
}

\author{
Amira Ali *
}

\section{Introduction}

As much as any other kind of non-literary translation, scientific translation has been usually overlooked by scholars of Translation Studies "where sophisticated, conceptually dense theories are brought to bear on literary practice with non-literary translation seen as the realm of no-nonsense, commonsensical instrumentalism" (Cronin, 2003, p. 2). This is attributed mainly to the alleged universalism of scientific discourse, which implies that the universal truths of science cross linguistic and cultural borders untouched-a situation where translation can be easily considered as trivial. However, the actual study of scientific translation throughout history proves that "knowledge cannot escape its forms; and forms, in turn, must be recognized to have their determinations and involvements" (Montgomery, 2000, p. 269). Translators have usually intervened throughout history in scientific texts to popularize new forms of knowledge, either by appropriating the texts to their readers' epistemological orientations (Elshakry, 2008, p. 704) or challenging the prevalent scientific thought of their societies to enforce change as hypothesized in the reported study. This has been shown by Translation Studies scholars through setting scientific translation in its cultural and socio-political contexts to account for such refashioning of texts, yet they did so mostly from a historical perspective, especially in relation to the English-Arabic language pair (ElShakry, 2008, 2013; Selim, 2009). Some other studies have tackled scientific translation in the modern age, focusing mainly on institutional practices (such as the translation of Scientific American journal articles, etc.), rather than volunteer non-professional activities. This is evident, for instance, in the special issue of The Translator

\footnotetext{
* Senior Arabic Translation Reviewer at Nagwa Limited. This paper is derived from an unpublished M.A. thesis entitled "Volunteers as Agents of Change: A Study of the Translation of Hedging in Popular Science Texts into Arabic by Three Volunteer Translation Collectives" (Cairo University 2019), supervised by Prof. Heba Aref. Cairo Studies in English 2020(1): https://cse.journals.ekb.eg/
} 
journal of 2011, entitled Science in Translation, and in Hala Sharkas' work $(2009,2011)$ pertaining to translation into Arabic.

On the other hand, the scientific volunteer translation has also been largely overlooked by studies dealing with the increasing proliferation of self-organized networks of non-professional volunteers nowadays. To the researcher's best knowledge, the only study that examines a volunteer scientific translation effort is Maeve Olohan's study of the volunteer translation of a 19th century scientific journal entitled Scientific Memoirs (2012). However, Olohan's study tackles the phenomenon from a historical perspective rather than a modern-day one. This scarcity of studies is evident, in particular, in the English-Arabic language pair where the subversive and activist use of translation for the causes of political resistance has been the main concern of translation scholars concerned with volunteerism (e.g. Baker, 2009; Baker, 2016; Selim, 2016).

Aiming at filling this gap in previous studies, the reported study focused on a specific type of scientific writing, namely popular science which is considered by some scholars a sub-genre, not just a simplified version of that kind of writing (Liao, 2010, p. 46). Through popularization, science reaches out for the public in a process that can be considered as a kind of translation, namely "intralingual translation" which is a "rewording ... an interpretation of verbal signs by means of other signs of the same language" (Jakobson, 1959/2004, p. 114). Through recontextualizion, popular science transfers scientific knowledge into another form within a new context that has its own requirements and implications. In the process, popularizers make changes to the conventional English scientific discourse features, including impersonal structures, nominalizations, passive voice and hedging, so as to make the texts suitable for addressing different audiences and serving different purposes.

Focusing on hedging as one of those conventional English scientific discourse features, the reported study investigates whether volunteer translators abide by the dominating Anglophone norms of the source texts, or rather make shifts that effect a change to hedged propositions, alter the epistemic stance of the writer and manipulate the knowledge transferred. Hedges are "words whose meaning implicitly involves fuzziness - words whose job is to make things fuzzier or less fuzzy" (Lakoff, 1973, p. 471). More importantly, less attention is generally paid to culturally-oriented studies that utilize the growing awareness in Translation Studies of the complex relationship between translation on one hand and ideology, power and knowledge production on the other, so as to study hedging as a linguistic device that both influences and is influenced by such a relationship in general (e.g. Kranich, 2016; Liao, 2011; Vandepitte et al., 2011)_let alone in the English-Arabic pair. 
Attempting at filling the aforementioned gaps in previous studies, the study investigated three Arab volunteer scientific translation collectives, namely $I$ believe in Science, Syrian Researchers and Egyptian Researchers, which managed throughout the last decade to attract thousands of followers and hundreds of volunteers on social media through translating and editing thousands of articles on popular science from English into Arabic. In quantitative terms, the volume of articles those collectives produce and the number of their volunteers and followers can be deemed as an indicator of the degree of influence they have on the scientific knowledge they transfer and the readership they address. In the light of those numbers, the study analyzes how the hedges are rendered by volunteers in the three collectives into Arabic, with the aim of answering its research question: How do the selected volunteer translation collectives contribute to the production of scientific knowledge in Arabic as reflected in their rendering of hedging devices?

\section{Volunteerism in Popular Science Translation: A Transfer or Production of Knowledge?}

Described by Sharon O'Brien and Reinhard Schäler (2010) as a "spectre [that] is haunting the translation industry - the spectre of translators taking charge" ( $p$. 1), volunteer translation has been recently one of the main topics of study in Translation Studies. Trying to delineate this new topic of study, researchers have been giving several names to the phenomenon that are usually used interchangeably in the literature, including user-generated translation (UGT), collaborative translation, community translation, volunteer translation, etc. However, the reported study used the term "volunteer translation" recommended by the translation scholar Anthony Pym who justifies his use by saying that the main aspect which distinguishes this kind of translation is that it is done for free. Such a concept captures what eludes other terms used by scholars in the field, which "seem shot through with activist ideologies, all of which are very well meant, and none of which highlight the most problematic feature concerned" (Pym, 2011, p. 97). That is why "volunteer translation" used in this study to stress the "working-for-free" aspect highlights the "free-willingness" of volunteer translators which sets them apart from the capitalistic constraints of monetary payment and client instructions. That makes the linguistic choices made by them worth investigating to identify their implications for the scientific knowledge they transfer.

Despite that trend of studying volunteerism in translation because of its assumed democratizing and revolutionizing impact on translation and Translation Studies, it is claimed by some scholars that the phenomenon is not 
that new and is rather rooted in history. It is contended that collaboration in translation, or what is called Translaboration, is "anything but a recent, let alone new phenomenon" (Alfer, 2017, p. 277). The history of collaborative translational projects goes back to antiquity (Cordingley \& Manning, 2017; Jiménez-Crespo, 2017). However, what is new is the convergence between the producers and consumers (prosumers) of translation, which is made possible by the widespread new media technologies that blur the lines between production and consumption, allowing consumers to assume power through appropriating media content to serve their own ends within the context of a participatory culture (Jenkins, 2009, p. 8).

That cooperation among prosumers of new media through formation of selforganized structures in defiance of competitive institutional entities has been conceptually examined by the media scholar Christian Fuchs, who argues for a dialectical conception of social self-organization that considers the relationship between social structures and agents as a mutual one rather than as one determining the other (Fuchs, 2002, p. 1). Looking at online volunteer translation, as a social activity, from that perspective suggested by Fuchs, it becomes clear how modern technological and media structures, facilitated by globalization, have resulted in a top-down emergence of cooperative volunteerism as a new feature of social actions, which has in turn led to the bottom-up rise of online networks as a new phenomenon in translation as a social structure. This reinforces the agency of translators as social beings who live within a structure of certain norms and rules which influence their actions, yet "they are creative and conscious beings that have a certain degree of freedom of action and thinking" (Fuchs, 2002, p. 45). Such an approach to translation in the framework of volunteerism, as being an ideologically-oriented rather than an objective and neutral process as usually perceived, has opened the door for utilizing it as a means of resistance, either politically against authoritarian regimes (Baker, 2016, Selim, 2016, Tymoczko, 2000), aesthetically against mainstream media (Li 2015, Pérez-González, 2006, 2012, 2013, 2014), or scientifically as reflected in the work of the volunteer collectives investigated in the reported study.

There has always been a reciprocal impact between scientific knowledge production and the socio-political circumstances of its age, as reflected in the recent cultural turn in Translation Studies. Therefore, as scientific "truths" are sociologically contingent constructions that vary from one period of history to another, such a reality paves the way for appropriating this kind of knowledge to achieve the goals of interest groups with partisan agendas. These agendas could be either imperial, utilitarian, humanitarian, racist, resistant, democratic, 
or nationalist and so on (e.g. Baker, 2006; El-Sharky 2008, 2013; Selim, 2009). This potential of appropriation becomes more pronounced when knowledge is in motion due to the change of context and readership, such as when it is transferred intralingually through popularization using the same language, or interlingually through translation from one language to another. Thus, the aim of the reported study was to shed light on the circumstances within which volunteer translators practice their activism in the scientific field and drive their translational decisions.

\subsection{Self-organization as a Means of Science Activism in the Arab World}

The reported study focused on three of the pioneer collectives concerned with popularizing science to the Arab public through translation, namely I believe in Science, Syrian Researchers and Egyptian Researchers. The rationale behind selecting those initiatives in particular has to do with their voluminous production evident in the number of articles they publish, their attractiveness to participants as indicated by the number of volunteers contributing to them, and the scale of their outreach reflected in the number of their followers on social media networks. Those quantitative criteria are considered a measure of the degree of influence the selected collectives have on the scientific knowledge they transfer and the readership they address. However, that popularity among science advocates was met with animosity in another circles, namely the religious ones. Content-wise, the three collectives cover delicate matters that are religiously controversial for Arab communities, though they allege their being not driven by any ideological motives and their exclusive seeking of an unbiased dissemination of scientific knowledge. This paradox is clearly evident in their slogans; "I believe in science because it is the only known proven method" (I believe in Science) which alludes to the argument often made by atheists that they believe in science, rather than God, "Science is the Solution" (Syrian Researchers) which is also an allusion to the well-known slogan of the Muslim Brotherhood "Islam is the Solution", and "With science, we progress" (Egyptian Researchers) which implies as well that science, not any other ideology, is the right way to settle any kind of conflicts and fanaticisms.

The resonance those collectives, along with their slogans, has made in the cyberspace is quite evident in the counteractive initiatives, such as the Muslim Researchers, which were formed with the purpose of resisting the religiously controversial ideas those initiatives try to spread among the Muslims. The hostility towards those initiatives led even to sending death threats to Mouhannad Malek, the founder of Syrian Researchers, by ISIS which claimed that Malek is an advocate of evolution and likely to face retribution if he opts for 
a return to Syria (Plackett, 2014). The controversiality of content was, therefore, a crucial criterion for selecting the three collectives which devote sections on their websites for some of the most religiously thorny issues such as evolution, genetic engineering, and sexology. The articles analyzed in the study were then selected from those three sections in particular to capture the complexities and pressures the volunteer translators work under in those initiatives and whether their choices can tell us anything about their ideological position in the sciencereligion conflict, a conflict that is particularly pronounced in that part of the world, the Arab countries. The strong grip of religion on scientific knowledge is usually accused of being the main reason for the scarcity of Arab scientific production and poor representation of the Arab world in the international scientific field (Paulson, 2011). Apart from the authenticity of such claims, which is out of scope of the reported study, the aforementioned hostility against the selected collectives highlights the sensitive circumstances in which they carry out their work.

Moreover, the obstacles faced by scientific volunteers and advocates is not limited to the regional level only. Generally speaking, popularizers of science have usually been impelled by journalistic pressures to sensationalize propositions and confer more certainty on the scientific "facts" they report on (Fahnestock, 1986, p. 275). Such pressures are currently taking a new turn in what is called nowadays a "post-truth" era. The term, which has been chosen in 2016 the word of the year by the Oxford Dictionaries, is defined as "relating to or denoting circumstances in which objective facts are less influential in shaping public opinion than appeals to emotion and personal belief' (Post-truth, n.d.). The looming loss of truth, as indicated by that term, has made concerned entities point an accusing finger at the openness and participatory practices facilitated by the new media for facilitating the dissemination of fake news, including "pseudoscience" that in turn led to a new wave of science denialism. In other words, what was applauded before for the rise of participatory culture and resistance against authoritarian traditional media is currently being frowned upon as its ugly sides began to reveal. Consequently, many voices have raised in scientific circles regarding the role science advocates and professionals should play nowadays, saying that "it is extremely important that scientists themselves, in various ways, actively engage in communication about science, including the mass media and Internet communication" (Pavić \& Šundalić, 2017, p. 42).

The founders of the selected volunteer translation collectives seem to be quite aware of that dilemma and assume responsibility as scholars and scientists to face it, as per their own words. For instance, Muhannad Malek, the postdoctoral researcher and founder of the Syrian Researchers, said that he found the 
collective because of "the irritating and seemingly omnipresent gullibility of social media users during the Arab Spring ... people typically accepted tweets and posts as gospel truth despite the absence of a clearly identified source, which led to misunderstandings and the viral spreading of myths" (Plackett, 2014). Malek decided to counteract the drawbacks of spreading myths by media using the same platforms. This has been also referred to by the founders of I believe in Science (Nabeel, 2017) and Egyptian Researchers (Shibl, 2016). Through selforganization, they assume their responsibility as scientific scholars, while reshaping the structures they work in by utilizing what capitalistic media structures offer them to serve their own activist agendas and making use of the potentials of manipulating certain linguistic features, such as hedges.

\subsection{Hedging and Manipulating Truth}

Against this backdrop of truth manipulation and its implications on science in our age, the reported study focused on one of the conventional English scientific discourse features, which is hedging that is closely related to the posttruth dilemma. "Hedges" was first used as a linguistic term by George Lakoff (1973) with the meaning of "words whose meaning implicitly involves fuzziness - words whose job is to make things fuzzier or less fuzzy" (p. 471). Hedging, thus, "refers to any linguistic means used to indicate either a) a lack of complete commitment to the truth value of an accompanying proposition, or b) a desire not to express that commitment categorically" (Hyland, 1998, p. 1). Since its introduction to linguistics, hedges have been considered as one of the conventional semantic features of scientific writing until it was suggested by Greg Myers (1989) that hedging was more than a semantic feature that serves the assumed neutrality and objectivity of scientific writing (along with impersonalization, passive voice, nominalization, etc.). Adopting that opinion, Myers moved hedging to the field of pragmatics in which it is looked at as an interactive feature that is governed by the social relations between the participants in discourse (p. 1-35).

As being dictated by the context in which it is used, hedges as a pragmatic feature have raised scholarly interest in investigating the causes and effects of handling and manipulating those devices when transferred into a new context with its own social relations between discourse participants. The implications of this transfer are evident either in translating scientific discourse intralingually (e.g. Crismore \& Vande Kopple, 1997; Fahnestock, 1986; Kranich, 2016; Varttala, 2001) or interlingually (e.g. Kranich, 2009; Markkanen \& Schröder, 1989; Vandepitte et al., 2011) to address a new readership. Cases of study have ranged from myths that have remarkable consequences on our lives, such as the 
alleged inferiority of girls to boys in mathematical ability (Fahnestock, 1986) and the claimed hierarchy of people based on their complexion (Baker, 2006), to the less noticeable alterations in the genre of scientific writing in the target language (Kranich, 2016; Liao, 2011).

\section{Data Collection and Methodology}

The study analyzed ninety articles compiled manually from the three selected initiatives, specifically thirty articles from each. Those initiatives are used collectively to represent a wider range of similar groups in the Arab cyberspace. The publication dates of the selected articles range from 2011 to 2018, and the duration of data collection extended from 2017 to 2018. As for the criteria of selecting articles, the first criterion was the clarity of comparison between STs and TTs, so only articles that are directly translated from certain English articles are selected, while articles edited from more than one ST were excluded. The second criterion was the controversiality of the articles, thus articles on the religiously contentious issues of evolution, genetic engineering and sexology were chosen for analysis.

In terms of methodology, the study employed a mixed method of quantitative and qualitative approaches to data analysis. The first quantitative approach is based on Ken Hyland's taxonomy of hedges introduced in his book Hedging in Scientific Research Articles (1998), which is, to the best of the researcher's knowledge, the most exhaustive taxonomy of hedges ever introduced. Based on that taxonomy, the articles underwent a four-step analysis. The first step was a surface-based analysis in which the articles were searched thoroughly to spot any hedges, relying on the detailed list introduced by Hyland (1998, p. 120-40). The identified hedges were then categorized as per Hyland's pragmatic categorization. In the third step, hedges were compared to their Arabic translations to spot any optional translation shifts that affect the degree of certainty conveyed, and then shifts were quantitatively measured to decide whether they reflect a certain trend in the collectives' translation strategies or not. Finally, the findings of the first three steps were qualitatively analyzed to identify their potential reasons and consequences. This has been achieved through looking at the production of scientific knowledge in the TTS and the volunteer translators' decision making process ending in either drifting towards the Anglophone linguistic features or intervening in the text to spread a knowledge that contradicts their audience's religious ideologies, but serves their own ideological agenda. 


\section{Data Analysis}

\subsection{Quantitative Analysis}

It has been suggested by this study that the activist translators in the three collectives do tend to make optional translation shifts that render the TTs more certain than the STs, while handling hedges. As per the quantitative analysis, the percentage of shifts in translating hedges in the whole corpus is $45 \%$ percent, which means that around half the instances of hedging in the STs have undergone shifts that led to a divergence in the degree of certainty expressed by the propositions of the original writers of STs. Out of the 397 shifts identified in the TTs, $363(91 \%)$ have resulted in a change in the degree of certainty conveyed by the hedged propositions through moving them towards less hedging, that is to say a higher degree of certainty, or towards more hedging and, accordingly, a lesser degree of certainty. It has also been found that shifts towards less hedging, through omission or other kinds of shifts, are much higher $(74 \%)$ than shifts towards more hedging through addition and other shifts (18\%). This makes propositions in the Arabic popular science articles corpus more certain compared with the original English STs.

Omissions are found to be the most frequent optional translation shift in the corpus as a whole (59\%) and in each collective. As illustrated by the examples below, the impact of omitting the hedge altogether is significant, especially when considering its optionality. In Example One, the truth content disjunct adverb "apparently", which constitutes a reliability accuracy-oriented hedge, is rendered more certain through using the passive verb only without the accompanied epistemic adverb. As for Example Two, the writer-oriented hedge manifest in the pronoun "he," using attribution to literature via the third person pronoun alluding to Darwin in the ST, and the epistemic adverb "perhaps" are omitted altogether in the TT, signalling an increased certainty in the sentences dealing with the animal in question.

\section{Example 1:}

ST: As a result, the team was excited to find that, unlike other kinds of DNA, the Neanderthal Y chromosome DNA was apparently not passed to modern humans during this time.

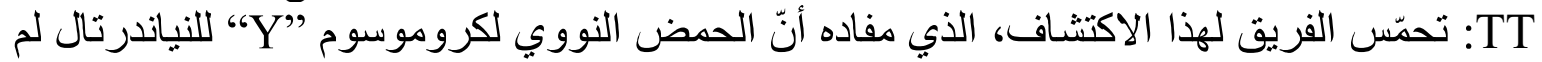

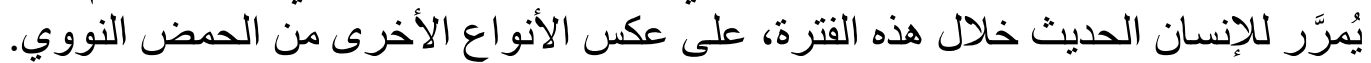

BT: The team was excited to find that the Neanderthal Y chromosome DNA was not passed to modern humans during this time, unlike other kinds of DNA.

("Modern man lack," 2016) 


\section{Example 2:}

ST: Toxodon, with a rhino's body, hippo's head and rodent-like teeth which he described as "perhaps one of the strangest animals ever discovered". ولئا التوكسودون (Toxodon) الذي له جسم وحيدات القرن، ور أس فرس النهر، وأسنان القوارض، ولهذا يعتبر أحد أغرب الحيو انات الئكتشفة إطلاقاً!

BT: Toxodon, with a rhino's body, hippo's head and rodent-like teeth, and thus is considered as one of the strangest animals ever discovered.

(Marchant, J., 2015)

As for the hedges that shifted towards more certainty through strategies other than omission, they were found to belong mainly to two categories, namely epistemic verbs and modal verbs, based on Hyland's taxonomy (1998) used in the surface-based analysis. As n in Example Three below, the writer-oriented hedge, made through attributing the proposition to a certain researcher by using the epistemic evidential quotative verb "say," rendered more affirmatively using the verb "يؤكد", which means "affirms", in the TT. As for Example Four, the reliability accuracy-oriented hedge using the modal verb "may" is translated into a verb indicating certainty through using "قد" with a past tense verb in Arabic. In Arabic, "قد " indicates an entirely different degree of certainty when it is added to present tense verbs as compared to its addition to past tense verbs; it indicates qualification when added to a present tense verb, whereas it conveys certainty when added to past tense verbs (Omar et al., 1994, p. 319). The shift in the modal verb, consequently, has led to a complete change in the degree of certainty conveyed by the sentence.

\section{Example 3:}

ST: ... although he says it is too early to try to directly link the epi-marks to any particular environmental exposure...

يؤكد أن هذه الدر اسات ما تز ال قاصرة عن إعطاء إثبات علمي كافٍ لعلاقة

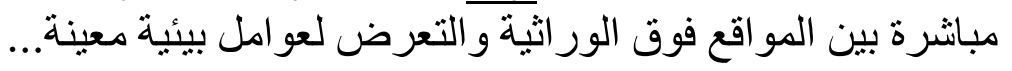

BT: ...but Vilain affirms that those studies are still incapable of providing enough scientific evidence of a direct link between epi-marks to any particular environmental exposure...

(Reardon, S., 2015)

\section{Example 4:}

ST: Because the birds used to live on an archipelago, this suggests that ... they may have evolved to suit different living conditions on different islands 
مبما جما أنّ الطيور كانت تعيش في أرخبيل، فإن هذا يشير إلى أنها قد تطورت لتلائم ظروف معيشة

مختلفة على جزر متعددة

BT: Because the birds used to live on an archipelago, this suggests that they had evolved to suit different living conditions on different islands

(Starr, M., 2018)

The potential causes and implications of the findings of that quantitative analysis has then been investigated in the following qualitative analysis. At that subsequent analytical stage, discussed in the next section, the causes and results of translating hedges in the corpus were interpreted in terms of the functions of hedges suggested by Hyland on the levels of content accuracy and writer-reader relationship.

\subsection{Qualitative Analysis}

According to Hyland, content-oriented hedges "mitigate the relationship between propositional content and a non-linguistic mental representation of reality" (1998, p. 162). This mitigation is motivated by either the writers' desire to state that the proposition is in accord with reality or to protect themselves from the negative consequences of poor judgment. The kind of hedges whose use is driven by the first motivation is called by Hyland accuracy-oriented hedges and "refer to the writer's desire to express propositions with greater precision in areas often characterized by revision and reinterpretation" (Hyland, 1998, p. 162). However, when dealt with in the context of popularization, this revision and reinterpretation of scientific "facts" is not looked at as an inherent quality of scientific knowledge in specialized scholarly circles as Hyland contends, but rather as a result of the conception that scientific "truth" is not exclusive to scientists as an elite group and is rather socially constructed through communicating it to exoteric audiences, that is to say the lay public (Myers, 1989, p. 7). The precision of "facts" presented in popular science articles is quite different. That is because such articles are in fact journalism that reports on new findings, and thus their writers - and presumably translators - undergo pressures to reinforce the significance of the topic and sensationalize it through "removing hedges and qualifications and thus conferring greater certainty on the reported facts" (Fahnestock, 1986, p. 275).

Under the pressure of engaging the lay audience in the communication of science, the volunteer collectives, which are founded by presumably sociallyresponsible scientific scholars, have been turning hedged propositions into "truths" through omitting qualified statements and conferring more certainty on the facts they report. They seem to have fallen into the post-truth traps of 
sensationalizing persuasive communication, creating false expectations, and demotivating criticism (Salgado et al., 2018), which they principally take an issue with. A translation strategy which exemplifies this inclination to sensationalisation and creation of false expectations is the omission of hedging which is quite evident, but not limited to, in the titles of articles as shown in the examples below. Through those omissions, the volunteer translators forgo the advantages of hedges for the sake of reinforcing the status of certain scientific news as "facts" rather than qualified propositions. Hedges are advantageous as a positive politeness strategy that ensures that readers won't feel coerced to give up their old views, but rather persuade them in a polite way (Kranich, 2016, p. 133 ) or that indicates that the readers are addressed in the same way experts are and gives them the impression that they have an active role in the processes of communicating and producing scientific knowledge (Varttala, 2001, p. 194).

\section{Example 5:}

ST: HIV Genes Have Been Cut Out of Live Animals Using CRISPR: This same technique could be the key to providing better treatment and maybe even a cure for HIV.

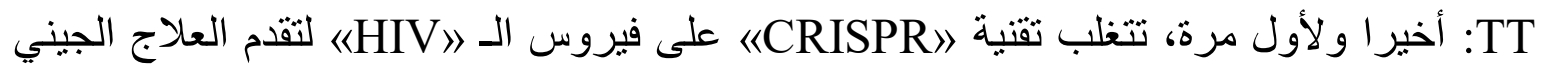

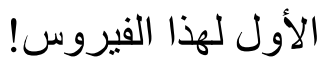

BT: Finally and for the first time, CRISPER Overcomes HIV and Provides the First Genetic Treatment for This Virus.

(Javelosa, J., 2016)

Example 6:

ST: Sexual orientation seems to be determined very early in life ... Based on these findings, we can say that environmental factors might play a role in sexual orientation.

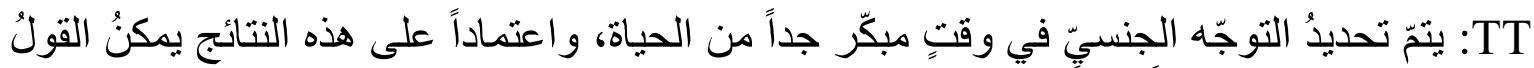

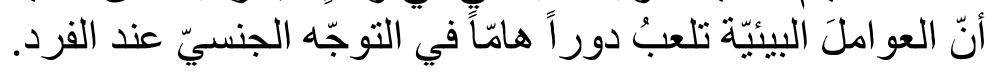

BT: Sexual orientation is determined very early in life, and based on these findings, it can be said that environmental factors play an important role in sexual orientation.

(Dotinga, R., 2016)

As for the writer-reader relationship in popular science articles translated by the volunteer collectives under study, it is quite complicated. This complexity pertains to the wider context in which those collectives operate, an eventuality that has arguably disrupted the traditional writer/reader dichotomy in the light of 
the previously mentioned prosumption phenomenon as well as the specific nature of the popular science genre they are dealing with. Popular science, in other words, has its bearings on the traditional conceptions of producers and consumers of scientific knowledge. As journalists, writers of popular science articles do not experience the tension researchers feel between their role as scientists and as journalists when they write articles for the public. Journalists only care about the general audience, and show solidarity with them using various strategies that include hedging, trying to avoid "insulting" those readers and make them feel part of the scientific community (Myers, 1989, p. 29). In the process, they are democratizing scientific knowledge production through involving lay readers in what has been usually perceived as a field exclusive to scientists as an elite group. When thinking about the position of the translator in this relationship, it can be argued that s/he mediates between a "mediator" (the journalist who is the connecting link between researchers and general audience) and readers.

Within this complicated mediating relationship, the visibility of volunteer translators in texts, as reflected in their optional translation shifts identified in the quantitative analysis, has led to a confusion of the voices speaking in the text, namely the voice of the journalist who writes the article, the voice of the researcher who is quoted by this journalist, and the voice of the translator who manipulates those two voices and adds his own. Not only does the translator intervenes in the text metaphorically, but also s/he may address their readership directly using direct speech as will be shown in the examples below:

Example 7:

ST: Natural Selection Is Causing a Decline in Human 'Education Genes', $\underline{\text { Say }}$ $\underline{\text { Scientists }}$

$$
\text { TT }
$$

BT: Natural Selection Is Causing a Decline in Human 'Education Genes'

(Crew, B., 2017)

Example 8:

ST: "It's a very sexy result, it's seductive, it's what evolutionary psychology would predict—and I think it's wrong," says psychologist Robert French

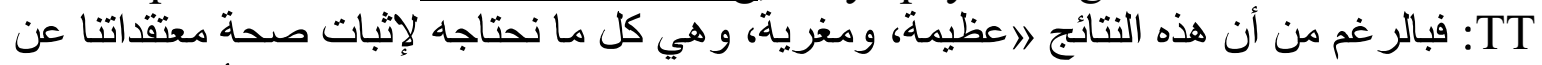

علم النفس التطوري)، كما قال عالم النفس ... (روبرت فرينش-Robert French)، إلا أنها خاطئة.

BT: Although these results are "great and sexy. They are all what we need to prove our beliefs in evolutionary psychology", as psychologist Robert French ... says, they are wrong.

(Matson, J., 2018) 
One last type of hedging that is related to the writer-reader relationship is reader-oriented hedging. The quantitative analysis has demonstrated that this category represents the most frequent type of hedges added to TTs in the form of direct questions (11 out of 17 in I believe in Science, 27 out of 30 in Syrian Researchers, and 9 out of 13 in Egyptian Researchers). According to Hyland (1998), questions give the impression that the writer seeks a response from the reader, and thus "involve the reader closely in the research and convey the communality of the scientific quest" (p. 183). In addition to adding questions to the TTs, volunteer translators use this strategy to superimpose their own voices on texts through speaking directly to readers and asking them for their opinion, as identified in the examples below. However, it is worth mentioning here that this kind of questions has been observed in the Syrian Researchers collective only, which implies that it is rather a stylistic preference of this collective in particular, rather than a common feature of popular science translation into Arabic in general.

\section{Example 9:}

ST: Japanese Scientists Just Got a Huge Step Closer to Creating Human Babies From Blood Cells

$$
\text { TT هل اقترب العلماء اليابانيون خطوةً من تخليق أجنة بشرية من خلايا الدم؟! }
$$

BT: Did Japanese Scientists Get a Step Closer to Creating Human Embryos From Blood Cells?!

(Johnson, C., 2018)

Example 10:

ST: N/A

ما رأيك عزيزي المتابع؟ هل يمكن أن نصل إلى مستقبل يصبح فيه هذا خيارًا آخر للإنجاب؟ :TT

BT: What do you think, dear follower? Could this technique be one day an alternative to reproduction?

(Rehm, J., 2018)

\section{Concluding Remarks}

It has been shown by the study that the translators in the selected volunteer translation collectives tend to confer more certainty on the hedged propositions found in the English source texts when they translate them into Arabic through optional translation shifts, as shifts towards less hedging are much more prominent with a percentage of $74 \%$ than shifts towards more hedging (18\%). This means that the volunteer translators contribute to the knowledge they 
transfer by making the corpus of Arabic popular science articles feature more certain propositions than what is originally found in the STs. In doing so, the volunteer collectives effect a serious change to the knowledge they transfer as a result of presenting scientific claims as truths in their attempt to allure the lay Arab readers to accept them. Furthermore, despite the primacy of English as a lingua franca, especially in scientific discourse, the study has demonstrated a contradicting tendency on the part of the volunteer translators to drift away from the linguistic constrains of the Anglophone textual norms, of which hedging is a distinct feature. Such a tendency may be the byproduct of the translators' hunger to demonstrate their agency either consciously or unconsciously in the TTs. This contradiction is reflected in the fact that they opted for making shifts that decreased the presence of hedges in Arabic popular science articles rather than amplifying it. Through introducing these changes to TTs, volunteer translators have taken away from their lay readers the advantageous, interactive hedging that allows for participation in knowledge communication and production.

\section{References}

Alfer, A. (2017). Entering the translab: Translation as collaboration, collaboration as translation, and the third space of 'translaboration'. Translation and Translanguaging in Multilingual Contexts, 3(3), 275-290

Baker, M. (2006). Translation and activism: Emerging patterns of narrative community. The Massachusetts Review 47(3), 462-484.

Baker, M. (2009). Resisting state terror: Theorizing communities of activist translators and interpreters. In E. Bielsa \& C. Hughes (Eds.), Globalisation, political violence and translation (pp. 222-242). Palgrave Macmillan.

Baker, M. (Ed.). (2016). Translating dissent: Voices from and with the Egyptian revolution. Routledge.

Cordingley, A., \& Manning, C. (2017). Collaborative translation: From the Renaissance to the digital age. Bloomsbury.

Crew, B. (2017, April 6) الانتقاء الطبيعي يسبب تدنيًا في جينات التعلّم لدى البشر [Natural selection is causing a decline in human education genes]. (Kazem, H. Trans.) Retrieved from https://www.syr-res.com/article/12968.html

Crismore, A. \& Vande Kopple, W. (1997). Hedges and readers: Effects on attitudes and learning. In R. Markkanen \& H. Schröder (Eds.), Hedging and discourse. Approaches to the analysis of a pragmatic phenomenon in academic texts (pp. 83-113). Walter de Gruyter.

Cronin, M. (2003). Translation and Globalization (p. 2). Routledge. 
Dotinga, R. (2016, March 5) المثلية الجنسية بين الماضي و المستقبل [The past and future of homosexuality]. (Alshamandi, W. Trans.) Retrieved from https://www.syrres.com/article/9487.html

Elshakry, M. (2008). Knowledge in motion: The cultural politics of modern science translations in Arabic. Isis, 99(4), 701-730.

Elshakry, M. (2013). Reading Darwin in Arabic, 1860-1950. The University of Chicago Press.

Egyptian Researchers. (n.d.). Timeline [Facebook page]. Retrieved from https://www.facebook.com/pg/EgyptianResearchers/.

Fahnestock, J. (1986). Accommodating science: The rhetorical life of scientific facts. Written Communications, 3(3), 275-96

Fuchs, C. (2002). Concepts of social self-organisation. INTAS Project "Human Strategies in Complexity. Philosophical Foundations for a Theory of Evolutionary Systems" Research Paper No. 4 (pp. 1-69). Vienna University of Technology. Retrieved from http://www.self-organization.org/results/papers/pdf/hsicpaper4.pdf.

Hyland, K. (1998). Hedging in Scientific Research Articles (pp. 120-83). John Benjamins Publishing Company.

I believe in Science. (n.d.). Timeline [Facebook page]. Retrieved from https://www.facebook.com/IbelieveInSci/.

Jakobson, R. (1959/2004) 'On linguistic aspects of translation'. In L. Venuti (Ed.), The translation studies reader (2nd ed., pp. 138-43). Routledge.

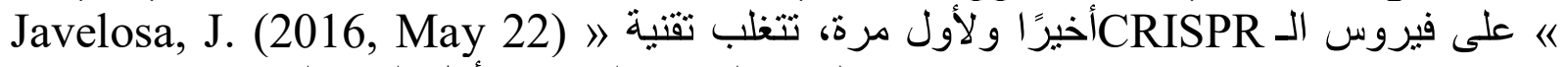
»HIV] [Finally and for the first time, CRISPER Overcomes HIV and provides the first genetic treatment for this virus.]. (Taha, A. Trans.) Retrieved from https://cutt.ly/5u1scNI

Jenkins, H. (2009). Confronting the challenges of participatory culture: Media education for the 21st Century (p. 8). MIT Press.

Jiménez-Crespo, M. (2017). Crowdsourcing and online collaborative translations. John Benjamins Publishing Company.

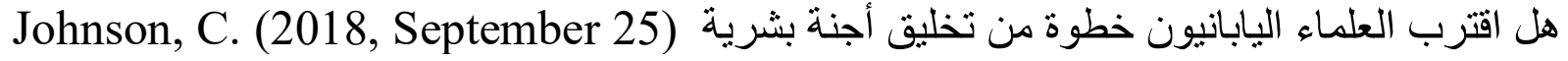
[Did Japanese scientists get a step closer to creating human embryos from blood cells?!]. (Mamdouh, S. Trans.) Retrieved from https://ibelieveinsci.com/?p=53627Kranich, S. (2009). Epistemic modality in English popular scientific articles and their German translations. transkom 2(1): 26-41

Kranich, S. (2016). Contrastive pragmatics and translation. Evaluation, epistemic modality and communicative styles in English and German. John Benjamins. 
Lakoff, G. (1973). Hedges: A study of meaning criteria and the logic of fuzzy concepts. In P. Peranteau, J. Levi \& G. Phares (Eds.), Papers from the Eighth regional meeting of the Chicago Linguistic Society (pp. 183-228). Chicago University Press.

Liao, M. (2010). Translating science into Chinese: An interactive perspective. The Journal of Specialised Translation, 13, 44-60.

Liao, M. (2011) Interaction in the Genre of Popular Science. The Translator, $17(2), 349-368$

Li, D. (2015). Amateur translation and the development of a participatory culture in China - A netnographic study of the last fantasy fansubbing group [Doctoral dissertation, University of Manchester]. Manchester eScholar. https://www.escholar.manchester.ac.uk/api/datastream?publicationPid=ukac-man-scw:273854\&datastreamId=FULL-TEXT.PDF

Marchant, J. (2015, April 22) العلماء يحلون لغزًا قديًًا من ألغاز شجرة العائلة التطورية (A) [Scientists solve an old mystery of the evolution tree]. (Al-Saleh, M. Trans.) Retrieved from https://www.syr-res.com/article/6220.htmlMarkkanen, R. \& Schröder, H. (1989). Hedging as a translation problem in scientific texts. In C. Lauren \& M. Nordman (Eds.) Special language: From humans thinking to thinking machines (pp. 171-79). Multilingual Matters.

Matson, J. (2018, June 18) في عيد الأب، نجيب على السؤال الخالد: من المسؤول عن شكل أنفاك؟ [On Father's Day, we answer the eternal question: Who is responsible of the shape of your nose?]. (Youssef, O. Trans.) Retrieved from https://cutt.ly/eu1sMJ8

لماذا (2016, July 9) (ack Y chromosome genes from Neanderthals. [Why does modern man lack Y chromosome genes from Neanderthals?] (Gamal, B. Trans.) Retrieved from https://cutt.ly/DulaGrVMontgomery, S. (2000). Science in translation: Movements of knowledge through cultures and time (p. 269). The University of Chicago Press.

Myers, G. (1989). The Pragmatics of politeness in scientific articles. Applied Linguistics, 10, 1-35.

Nabeel, G. (2017, June 9). An online movement translates academic articles into Arabic. Al-Fanar Media. Retrieved from https://www.alfanarmedia.org/2017/06/online-movement-publishes-academic-translationsarabic/

O'Brien, S. \& Schäler, R. (2010). Next generation translation and localization: Users are taking charge. In Proceedings of translating and the computer, 32, 17-18. Retrieved from http://doras.dcu.ie/16695/1/Paper_6.pdf 
Olohan, M. \& Myriam S. C. (2011). The Translator: Science in Translation, $17(2)$.

Olohan, M. \& Myriam S. C. (2012). Volunteer translation and altruism in the context of a nineteenth-century scientific journal. The Translator 18(2), 193215.

Omar, A., Zahra, M., \& Abdel-Latif, M. (1994). النحو الأساسي [Basic grammar] (p. 319). Dar Al-Salasel.

Paulson, Steve (2011, June 19). Does Islam Stand Against Science? Chronicle. Retrieved from https://www.chronicle.com/article/Does-Islam-StandAgainst/127924

Pavić, Ž., \& Šundalić, A. (2017). Science in post-truth society: New media and social perception of Science. Media, Culture and Public Relations, 1, 35-46.

Pérez-González, L. (2006). Fansubbing Anime: Insights into the butterfly effect of globalisation on audiovisual translation. Perspectives: Studies in Translatology 14(4), 260-77.

Pérez-González, L. (2012). Amateur subtitling and the pragmatics of spectatorial subjectivity. Language and intercultural communication 12(4), 335-352.

Pérez-González, L. \& Susam-Saraeva, Ş. (2012). Non-professionals translating and interpreting: Participatory and engaged Perspectives. The Translator 18(2), 149-165.

Pérez-González, L. (2013). Amateur subtitling as immaterial labour in digital media culture: An emerging paradigm of civic engagement. Convergence: The International Journal of Research into New Media Technologies 19(2), 157-175.

Pérez-González, L. (2014). Translation and new(s) media: Participatory subtitling practices in networked mediascapes. In H. Juliane (Eds.), Translation: A multidisciplinary approach (pp. 200-221). Palgrave Macmillan.

Plackett, B. (2014, October 14). Bringing Science to the Arabic-speaking masses. Al-Fanar Media. Retrieved from https:/www.alfanarmedia.org/2014/10/bringing-science-arabic-speaking-masses/

Post-truth (n.d.). In Oxford Dictionaries online. Retrieved from https://en.oxforddictionaries.com/definition/post-truth.

Pym, A. (2011). Translation research terms: A tentative glossary for moments of perplexity and dispute. In Anthony Pym (Eds.), Translation research projects 3 (pp. 75-110). Intercultural Studies Group.

Reardon, S. (2015, November 4) المثلية الجنسية وراثيًا ]The genetics of homosexuality]. (Alzouabi, H. Trans.) Retrieved from https://www.syrres.com/article/8295.html 
Rehm, J. أول مرة؛ أجنة من آباء متماتلي الجنس! (2018, October 13) [For the first time, embryos from same-sex parents!]. (Ghadeer, J. Trans.) Retrieved from https://www.syr-res.com/article/16176.html

Salgado, J., Alegre-Cebollada, J., Daura, X., \& Giráldez, T. (2018). Science and post-truth [Editorial]. Biofisica, 10, 7-10. Retrieved from https://www.uv.es/biophys/sbe/10/PDFsite/ScienceAndPosttruth.pdf.

Selim, S. (2009). Languages of civilization: Nation, translation and the politics of race in colonial Egypt. The Translator, 15(1), 139-56.

Selim, S. (2016). Text and context: Translating in a state of emergency. In Baker, M. (Eds.), Translating dissent: Voices from and with the Egyptian revolution (pp. 77-87). Routledge.

Sharkas, H. (2009). Translation quality assessment of popular science articles: Corpus study of the scientific American and Its Arabic version. trans-kom 2(1): 42-62.

Sharkas, H. (2011). The use of glossing in modern original scientific writing in Arabic. The Translator, 17(2), 369-389

Shibl, N. (2016, August 13). Egyptian researchers: Reviving Egypt's science scene. BECAUSE. Retrieved from http://because.bz/education/egyptianresearchers-reviving-egypts-science-scene.

Starr, M. (2018, February 16). داروين محق من جديد: أحفورة رائعة تظهر تطور العصافير Darwin is right again: An amazing fossil shows earliest birds evolved just as he predicted]. (Masad, N. Trans.) Retrieved from https://ibelieveinsci.com/?p=44360

Syrian Researchers. (n.d.). Timeline [Facebook page]. Retrieved from https://www.facebook.com/pg/Syrian.researchers/about.

Tymoczko, M. (2000). Translation and political engagement: Activism, social change and the role of translation in geopolitical shifts. The Translator 6(1), 23-47.

Vandepitte, S., Vandenbusschea, L., \& Algoeta, B. (2011). Travelling certainties: Darwin's doubts and their Dutch translations. The Translator, $17(2), 275-299$.

Varttala, T.A. (2001). Hedging in scientifically oriented discourse: Exploring variation according to discipline and intended audience [Unpublished doctoral dissertation]. University of Tarnpereen Yliopisto. 